\title{
Contemporary issues on clopidogrel therapy: a critical appraisal
}

\author{
Davide Capodanno $\cdot$ Dominick J. Angiolillo
}

Received: 3 March 2009/Accepted: 5 March 2009/Published online: 31 March 2009

(C) SIMI 2009

Clopidogrel is a second-generation thienopyridine that blocks the adenosine diphosphate (ADP) $\mathrm{P}_{2} \mathrm{Y}_{12}$ receptor antagonist. Following the results of the pivotal Clopidogrel versus Aspirin in Patients at Risk of Ischaemic Events (CAPRIE) trial [1], it received approval from the Food and Drug Administration in 1997 and Conformité Européenne in 1998. Subsequent studies extend on the indications for its use in the setting of acute coronary syndromes (ACS) [2], ST-segment elevation myocardial infarction [3, 4] and percutaneous coronary intervention (PCI) [5, 6]. Despite the robust clinical findings and indications for clopidogrel usage derived from these large-scale clinical trials performed over the course of the past decade, which are clearly reflected in clinical practice guidelines [7-9], there are a large number of uncertainties regarding clopidogrel usage in daily real world practice. This is reflected by the plethora of publications dealing with clopidogrel over the course of the past several years. In a PubMed research, a total of 660 citations were identified from the years 20002005, which is almost sevenfold higher than that of the previous half-decade $(1995-2000 ; n=96)$. Strikingly, from years 2006 to 2008, the number of clopidogrel related citations is 827 (Fig. 1). It is quite certain that these figures will continue to increase over the course of the upcoming years with the introduction of novel antiplatelet agents that all have as their comparison agent clopidogrel, as this still represents the ADP $\mathrm{P}_{2} \mathrm{Y}_{12}$ receptor antagonist of choice until new recommendations appear [10].

D. Capodanno · D. J. Angiolillo ( $\square)$

Division of Cardiology, University of Florida College

of Medicine-Jacksonville, 655 West 8th Street,

Jacksonville, FL 32209, USA

e-mail: dominick.angiolillo@jax.ufl.edu
In Internal and Emergency Medicine, Patti et al. [11] sought to address some of the most debated topics surrounding optimal clopidogrel usage, particularly in patients undergoing PCI. The authors address five issues regarding clopidogrel treatment strategies that are frequently encountered in daily clinical practice. The authors have addressed these aspects based on their accruing contribution to the scientific literature, having provided several landmark studies that have also set the basis for continuing research in the field. Therefore, the authors should not only be commended for their perspectives provided in this nicely done review article, but most importantly for their dedication to this important field of interventional pharmacology. Below we summarize the aspects addressed by Patti et al. in their review manuscript and provide our critical perspective.

The first question addressed is: Is early clopidogrel treatment needed in patients with ACS treated medically or undergoing PCI? The authors fully address this question by providing data from trials supporting early clopidogrel initiation in patients with ACS, either treated medically or undergoing coronary revascularization [4-6]. While there are no doubts on the clinical benefit achieved with clopidogrel pretreatment, a question that arises from this consideration is the timing necessary to achieve such a benefit. As highlighted in the manuscript by Patti et al. [11], overall a long-pretreatment period $(\sim 12-15 \mathrm{~h})$ is required to achieve clinical benefits when using a $300 \mathrm{mg}$ loading dose, which is that approved by the FDA [12]. While high loading dose regimens $(\geq 600 \mathrm{mg}$ ) that accelerate platelet inhibitory processes may reduce this time frame, there is only limited data from small sample size studies on the clinical efficacy of this treatment strategy. In addition, despite the non-disputable clinical benefit achieved with clopidogrel pretreatment, many centers resist 
Fig. 1 Temporal trends of clopidogrel-related citations from 1991 to 2008

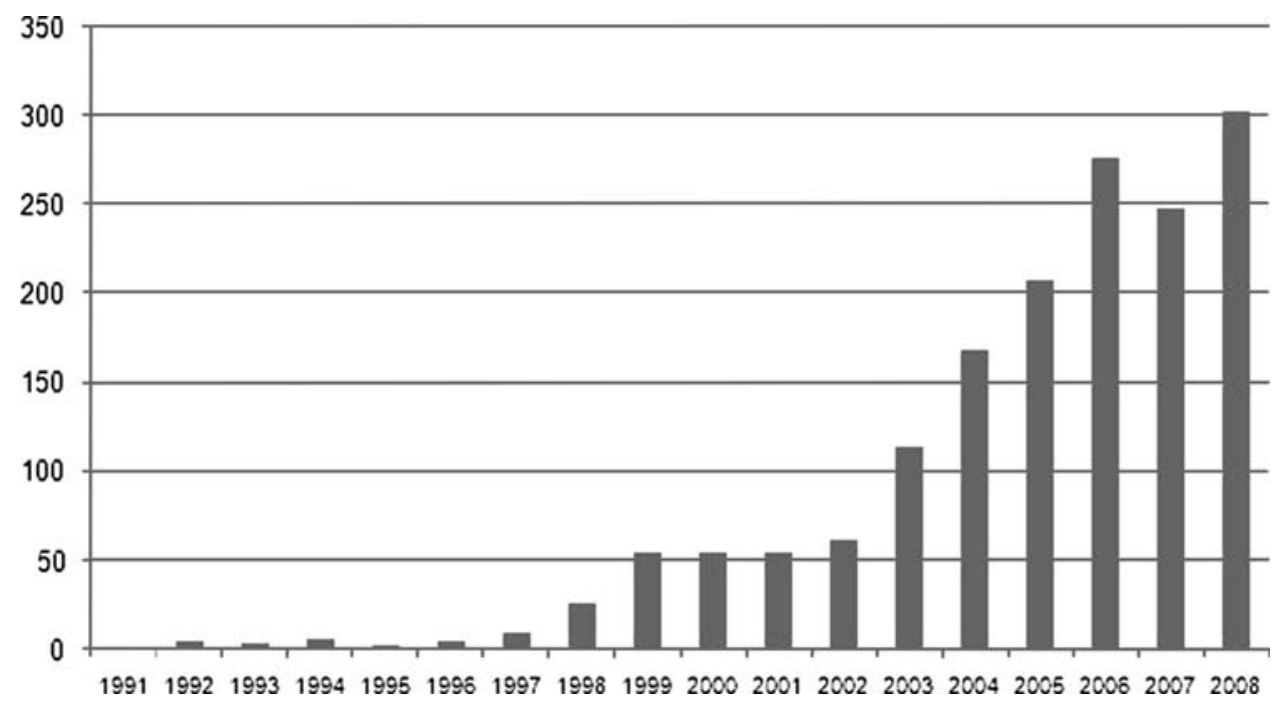

applying this strategy until coronary anatomy is known because of the irreversible effects of clopidogrel, which lead to delay (5-7 days) in case surgical revascularization is needed [7]. Indeed, the introduction of agents with reversible effects (e.g., ticagrelor, cangrelor, elinogrel) will be useful to overcome this limitation [10].

The second question addressed is: What is the optimal clopidogrel loading dose in patients undergoing PCI? The authors have previously reported favorable outcomes with a 600- versus a 300-mg loading dose in patients undergoing PCI [13]. Other studies have confirmed these findings that are in line with the more rapid and potent effects of this dosing regimen, and which now represents the loading dose of choice by most interventionalists. Importantly, the updated PCI guidelines have recently provided a class I indication for a $600 \mathrm{mg}$ dosing regimen, even though the data to support this are limited to relatively small samplesized studies [9]. It is for this reason that a $600 \mathrm{mg}$ clopidogrel dose is not approved by regulatory authorities. The ongoing CURRENT/OASIS-7 (Clopidogrel optimal loading dose usage to reduce recurrent events/optimal antiplatelet strategy for interventions) trial (ClinicalTrials.gov identifier NCT00335452), currently being performed in $\sim 20,000$ ACS patients with intent to undergo PCI, will provide the evidence to support if a $600 \mathrm{mg}$ loading dose strategy is more effective, without safety concerns, compared to the approved $300 \mathrm{mg}$ dose. It may be hypothesized that this aspect may lose some of its relevance with the introduction of new P2Y12 receptor antagonists, such as prasugrel (a third-generation thienopyridine), which has more prompt and potent antiplatelet effects even when compared to a $600 \mathrm{mg}$ clopidogrel loading dose and associated with better clinical outcomes [14].

The third question addressed is: In the context of a $600 \mathrm{mg}$ loading strategy, is pre-treatment with clopidogrel before PCI needed, or can this loading dose be given in the catheterization laboratory, before intervention, but after coronary anatomy is known? In line with what has been described above (question one), the authors address this very important clinical question. Indeed, the authors have provided important preliminary findings attempting to address this topic [15], which has only been approached in one other study [16]. While the authors provide their opinion as to which are the clinical scenarios in which a pre-treatment strategy can be omitted in favor of a $600 \mathrm{mg}$ loading dose administered directly when coronary anatomy is known, we believe that larger scale studies are warranted to most adequately address this question. Indeed, as stated above, the introduction of novel $\mathrm{P} 2 \mathrm{Y}_{12}$ receptor inhibitors, which are characterized by more potent effects and many of which have reversible properties, will potentially represent important treatment alternatives to overcome this dilemma [10].

The fourth question addressed is: What is the optimal clopidogrel strategy in patients on chronic clopidogrel therapy undergoing PCI? In clinical practice, a recurrent clinical question is how to manage clopidogrel treatment in patients already on maintenance therapy, who are admitted for an ACS or need to undergo PCI. Laboratory findings show that a reload with $600 \mathrm{mg}$ of clopidogrel enhances platelet inhibition in these patients, suggesting that this may be potentially beneficial in clinical scenarios, such as ACS/PCI, where greater platelet inhibition is warranted [17]. In their manuscript, Patti et al. [11] report their preliminary findings, addressing the clinical impact of this reload strategy, and show a clinical benefit in ACS, but not in stable patients undergoing PCI. While these data provide some important insights into this topic, it is important to underscore that larger-scale study targeted on specific populations, rather than assumptions derived from subgroup analysis, are warranted to best address both the safety and efficacy of clopidogrel reloading. 
The fifth and last question addressed is: Does the degree of clopidogrel response influence the clinical outcome in patients undergoing PCI? Over the course of the past several years, there have been numerous studies evaluating the prognostic implications of clopidogrel response variability [18]. Nevertheless, there are numerous questions that surround this topic [19]. These include: which platelet function test should be used? What is the timing of testing? What are the cutoff values to define patients as poor responders? Which patient-population needs to be studied? What must be done for a poor responder? The latter represents the most important issue because based on the currently available data, it remains unclear if any modification in treatment is cost-effective [19]. Therefore, in line with expert consensus, at the current time, platelet function testing should be reserved for research purposes only.

In conclusion, clopidogrel has entered a phase in which many unsolved questions have been accumulating, and which are likely to increase with the introduction of novel antiplatelet agents currently under clinical development. A critical analysis of the evidence collected till now is always useful to consolidate the current knowledge and to identify cues for continuous research. Such critical appraisal may thus form the basis of dedicated outcome studies that will better direct our approach to patients and practice guidelines.

Conflict of interest statement The author D. J. Angiolillo has received honoraria, for lectures and participation on advisory boards, from Bristol Myers Squibb, Sanofi-Aventis, Eli Lilly Co. and Daiichi Sankyo Inc. He has received honoraria from the medical companies, Portola, Novartis, Medicure, Accumetrics, Arena Pharmaceuticals and Astra Zeneca, and research grants from GlaxoSmithKline, Otsuka, Eli Lilly Co and Daiichi Sankyo Inc., and from medical companies such as Portola, Accumetrics, Schering-Plough, AstraZeneca and Eisai.

\section{References}

1. CAPRIE Steering Committee (1996) A randomised, blinded, trial of clopidogrel versus aspirin in patients at risk of ischaemic events (CAPRIE). Lancet 348:1329-1339

2. Yusuf S, Zhao F, Mehta SR, Chrolavicius S, Tognoni G, Fox KK (2001) Effects of clopidogrel in addition to aspirin in patients with acute coronary syndromes without ST-segment elevation. N Engl J Med 345:494-502

3. Chen ZM, Jiang LX, Chen YP, Xie JX, Pan HC, Peto R, Collins R, Liu LS, COMMIT (ClOpidogrel and Metoprolol in Myocardial Infarction Trial) collaborative group (2005) Addition of clopidogrel to aspirin in 45,852 patients with acute myocardial infarction: randomised placebo-controlled trial. Lancet 366:1607-1621

4. Sabatine MS, Cannon CP, Gibson CM et al (2005) Addition of clopidogrel to aspirin and fibrinolytic therapy for myocardial infarction with ST-segment elevation. N Engl J Med 352:11791189

5. Mehta SR, Yusuf S, Peters RJ et al (2001) Effects of pretreatment with clopidogrel and aspirin followed by long-term therapy in patients undergoing percutaneous coronary intervention: the PCICURE study. Lancet 358:527-533

6. Steinhubl SR, Berger PB, Mann JT 3rd, Fry ET, DeLago A, Wilmer C, Topol EJ, CREDO Investigators: Clopidogrel for the Reduction of Events During Observation. (2002) Early and sustained dual oral antiplatelet therapy following percutaneous coronary intervention: a randomized controlled trial. JAMA 288:2411-2420

7. Anderson JL, Adams CD, Antman EM, Bridges CR, Califf RM, Casey DE Jr, Chavey WE 2nd, Fesmire FM, Hochman JS, Levin TN, Lincoff AM, Peterson ED, Theroux P, Wenger NK, Wright RS, Smith SC Jr, Jacobs AK, Halperin JL, Hunt SA, Krumholz HM, Kushner FG, Lytle BW, Nishimura R, Ornato JP, Page RL, Riegel B; American College of Cardiology; American Heart Association Task Force on Practice Guidelines (Writing Committee to Revise the 2002 Guidelines for the Management of Patients With Unstable Angina/Non ST-Elevation Myocardial Infarction); American College of Emergency Physicians; Society for Cardiovascular Angiography and Interventions; Society of Thoracic Surgeons; American Association of Cardiovascular and Pulmonary Rehabilitation; Society for Academic Emergency Medicine (2007) ACC/AHA 2007 guidelines for the management of patients with unstable angina/ non ST-elevation myocardial infarction: a report of the American College of Cardiology/American Heart Association Task Force on Practice Guidelines (Writing Committee to Revise the 2002 Guidelines for the Management of Patients With Unstable Angina/Non ST-Elevation Myocardial Infarction): developed in collaboration with the American College of Emergency Physicians, the Society for Cardiovascular Angiography and Interventions, and the Society of Thoracic Surgeons: endorsed by the American Association of Cardiovascular and Pulmonary Rehabilitation and the Society for Academic Emergency Medicine. Circulation 116:148-304

8. Antman EM, Hand M, Armstrong PW, Bates ER, Green LA, Halasyamani LK, Hochman JS, Krumholz HM, Lamas GA, Mullany CJ, Pearle DL, Sloan MA, Smith SC Jr; 2004 Writing Committee Members, Anbe DT, Kushner FG, Ornato JP, Jacobs AK, Adams CD, Anderson JL, Buller CE, Creager MA, Ettinger SM, Halperin JL, Hunt SA, Lytle BW, Nishimura R, Page RL, Riegel B, Tarkington LG, Yancy CW (2008) 2007 Focused Update of the ACC/AHA 2004 Guidelines for the Management of Patients With ST-Elevation Myocardial Infarction: a report of the American College of Cardiology/American Heart Association Task Force on Practice Guidelines: developed in collaboration With the Canadian Cardiovascular Society endorsed by the American Academy of Family Physicians: 2007 Writing Group to Review New Evidence and Update the ACC/AHA 2004 Guidelines for the Management of Patients With ST-Elevation Myocardial Infarction, Writing on Behalf of the 2004 Writing Committee. Circulation 117:296-329

9. King SB 3rd, Smith SC Jr, Hirshfeld JW Jr, Jacobs AK, Morrison DA, Williams DO; 2005 WRITING COMMITTEE MEMBERS, Feldman TE, Kern MJ, O'Neill WW, Schaff HV, Whitlow PL, Adams CD, Anderson JL, Buller CE, Creager MA, Ettinger SM, Halperin JL, Hunt SA, Krumholz HM, Kushner FG, Lytle BW, Nishimura R, Page RL, Riegel B, Tarkington LG, Yancy CW (2008) 2007 Focused Update of the ACC/AHA/SCAI 2005 Guideline Update for Percutaneous Coronary Intervention: a report of the American College of Cardiology/American Heart Association Task Force on Practice Guidelines: 2007 Writing Group to Review New Evidence and Update the ACC/AHA/ SCAI 2005 Guideline Update for Percutaneous Coronary Intervention, Writing on Behalf of the 2005 Writing Committee. Circulation 117:261-295 
10. Angiolillo DJ, Bhatt DL, Gurbel PA, Jennings LK (2009) Advances in antiplatelet therapy: agents in clinical development. Am J Cardiol 103(Suppl):40A-51A

11. Patti G, Di Sciascio G (2009) Contemporary issues on clopidogrel therapy. Intern Emerg Med. doi:10.1007/s11739-008-0220-5

12. Steinhubl SR, Berger PB, Brennan DM, Topol EJ, CREDO Investigators (2006) Optimal timing for the initiation of pretreatment with $300 \mathrm{mg}$ clopidogrel before percutaneous coronary intervention. J Am Coll Cardiol 47:939-943

13. Patti G, Colonna G, Pasceri V, Pepe LL, Montinaro A, DI Sciascio G (2005) A randomized trial of high loading dose of clopidogrel for reduction of peri-procedural myocardial infarction in patients undergoing coronary intervention results from the ARMYDA-2 (antiplatelet therapy for reduction of myocardial damage during angioplasty) study. Circulation 111:2099-2106

14. Angiolillo DJ, Suryadevara S, Capranzano P, Bass TA (2008) Prasugrel: a novel platelet ADP P2Y12 receptor antagonist. A review on its mechanism of action and clinical development. Expert Opin Pharmacother 9:2893-2900

15. Patti G, Colonna G, Pasceri V (2007) Is $600 \mathrm{mg}$ in-lab clopidogrel loading equivalent to "upstream" pre-treatment in patients undergoing percutaneous coronary intervention? Results of the
ARMYDA-5 (antiplatelet therapy for reduction of myocardial damage during angioplasty) randomized trial. Late breaking clinical trials, TCT sessions. http://www.cardiosource.com/img/ armyda501.ppt

16. Widimsky P, Motovská Z, Simek S, Kala P, Pudil R, Holm F, Petr R, Bílková D, Skalická H, Kuchynka P, Poloczek M, Miklík R, Maly M, Aschermann M, PRAGUE-8 Trial Investigators (2008) Clopidogrel pre-treatment in stable angina: for all patients $>6 \mathrm{~h}$ before elective coronary angiography or only for angiographically selected patients a few minutes before PCI? A randomized multicentre trial PRAGUE-8. Eur Heart J 29:14951503

17. Kastrati A, von Beckerath N, Joost A, Pogatsa-Murray G, Gorchakova O, Schömig A (2004) Loading with $600 \mathrm{mg}$ clopidogrel in patients with coronary artery disease with and without chronic clopidogrel therapy. Circulation 110:1916-1919

18. Angiolillo DJ (2009) Variability in responsiveness to oral antiplatelet therapy. Am J Cardiol 103(Suppl):27A-34A

19. Angiolillo DJ, Suryadevara S, Capranzano P, Zenni MZ, Guzman LA, Bass TA (2009) Antiplatelet drug response variability and the role of platelet function testing: a practical guide for interventional cardiologists. Catheter Cardiovasc Interv 73:1-14 